\title{
KEDUDUKAN SAKSI INSTRUMENTAIR AKTA NOTARIS DALAM KAITANNYA DENGAN PASAL 16 AYAT (1) UNDANG-UNDANG NOMOR 30 TAHUN 2004 TENTANG JABATAN NOTARIS
}

\author{
Oleh \\ I Komang Sujanayasa*, Prof. Dr. Ibrahim R, SH.,MH, ,**, \\ Dr. I Gusti Ketut Ariawan.,SH.,MH** \\ Magister Kenotariatan Universitas Udayana \\ E-mail:info@aridewicollection.com
}

\begin{abstract}
Notaris sebagai pejabat umum yang berwenang membuat akta otentik sebagaimana diatur dalam Undang-Undang Nomor 30 Tahun 2004 tentang Jabatan Notaris sebagaimana yang telah diubah dengan Undang-Undang Nomor 2 Tahun 2014. Notaris sebagaimana diatur dalam Undang-Undang Jabatan Notaris wajib merahasiakan isi akta yang dibuatnya. Namun dalam akta notaris terdapat pula peranan 2 (dua) orang saksi yaitu saksi instrumentair yang dalam hal ini adalah karyawan notaris. Permasalahan yang dihadapi yaitu bagaimanakah kedudukan hukum saksi instrumentair dalam kaitannya dengan adanya ke wajiban notaris untuk merahasiakan segala sesuatu yang berkenaan dengan akta yang dibuatnya dalam Pasal 16 ayat (1) huruf $f$ UUJN Perubahan? dan sejauhmana tanggungjawab saksi instrumentair akta notaris sejalan dengan Pasal 16 ayat (1) huruf $m$ UUJN Perubahan?

Jenis penelitian ini adalah penelitian hukum normatif Penelitian hukum Normatif mencakup penelitian terhadap sistematika hukum, penelitian terhadap taraf sinkronisasi hukum, penelitian sejarah hukum dan penelitian perbandingan hukum. Penelitian ini beranjak dari terjadinya konflik norma antara Pasal 16 ayat (1) huruf $f$ dengan Pasal 16 ayat 1 huruf $m$ UUJN Perubahan. Sumber data yang dipergunakan dalam penelitian ini yaitu data primer dan data sekunder.

Hasil penelitian ini menunjukkan bahwa Saksi instrumentair dalam kaitannya dengan adanya kewajiban notaris untuk merahasiakan segala sesuatu yang berkenaan dengan akta yang dibuatnya dalam Pasal 16 ayat (1) huruf $f$ UUJN Perubahan, oleh undang-undang tidak diwajibkan secara tegas kepada para saksi untuk merahasiakan isi akta tersebut, sehingga apabila saksi instrumentair ini membocorkan isi dari suatu akta, maka perbuatan tersebut merupakan suatu perbuatan melawan hukum. dalam hal melakukan pengetikan dan penyusunan rancangan akta, karyawan notaris bertanggung jawab terhadap hasil pengetikan tersebut. Dalam peresmian akta, karyawan notaris memiliki tanggung jawab terhadap apa yang diperintahkan atau ditugaskan atau diminta oleh notaris untuk menjadi saksi dalam peresmian akta. Dengan demikian karyawan notaris tidak bertanggung jawab terhadap isi akta yang ditandatanganinya sebagai saksi, mengingat dari sifat kedudukannya sebagai karyawan yang hanya ditugaskan oleh notaris yaitu hanya sebatas untuk mempersiapkan akta tersebut.
\end{abstract}

Kata kunci : Kedudukan, SaksiInstrumentair, Akta, Notaris

\section{B A B I}

\section{PENDAHULUAN}

\subsection{Latar Belakang}

Kebutuhan masyarakat akan jasa Notaris sebagai pembuat akta semakin meningkat dalam kehidupan seharihari dikarenakan semakin banyaknya orang atau badan hukum melakukan perjanjian-perjanjian yang dituangkan dalam bentuk akta. Sebab Notaris adalah pejabat umum yang mempunyai wewenang untuk membuat akta otentik mengenai semua perbuatan, perjanjian dan penetapan yang diperintahkan oleh peraturan umum atau diminta oleh para pihak yang membuat akta. ${ }^{1}$

${ }^{1}$ Sudikno Mertokusumo, 2004, Arti Penemuan Hukum Bagi Notaris, Majalah Renvoi, Nomor 12, tanggal 3 Mei 2004, (selanjutnya disebut Sudikno Mertokusumo I) h. 49 
Undang-Undang Republik Indonesia Nomor 30 Tahun 2004 Tentang Jabatan Notaris, selanjutnya pula dilakukan perubahan sebagaimana diubah dengan Undang-Undang Republik Indonesia Nomor 2 Tahun 2014 tentang Perubahan Atas UndangUndang No. 30 Tahun 2004 tentang Jabatan Notaris (selanjutnya disebut UUJN Perubahan) Di dalam Pasal 1 angka 1 UUJN Perubahan, disebutkan bahwa "Notaris adalah pejabat umum yang berwenang untuk membuat akta autentik dan meiliki kewenangan lainnya, sebagaimana dimaksud dalam undang-undang ini atau berdasarkan undang-undang lainnya." Di dalam peresmian akta notaris diharuskan adanya kehadiran saksi. Saksi tersebut harus diyakini oleh notaris secara teliti jika ia tidak ingin menghadapi kerugian. Kedudukan dari para saksi wajib diketahui oleh notaris.

Sebagai alat bukti yang sah, Saksi adalah Seseorang yang memberikan kesaksian, baik dengan lisan maupun secara tertulis atau tanda tangan, yakni menerangkan apa yang ia saksikan sendiri (waarnemen), baik itu berupa perbuatan atau tindakan dari orang lain atau suatu keadaan ataupun suatu kejadian. ${ }^{2}$ Dalam suatu peresmian akta notaris diharuskan adanya dua orang saksi sebagaimana diatur dalam Pasal 16 ayat (1) huruf m UUJN Perubahan jo Pasal 40 ayat (1) UUJN Perubahan. Namun pada dasarnya dalam Undang-Undang Jabatan Notaris tidak mengatur mengenai jenis-jenis saksi yang

2 G.H.S., Lumban Tobing, 1999, Peraturan Jabatan Notaris, Erlangga, Jakarta, h. 168 diharuskan tersebut. Dalam ruang lingkup kenotariatan oleh para sarjana dikenal dua macam saksi, yang menurut pendapat Tan Thing Kie yaitu saksi kenal dan saksi instrumentair. ${ }^{3}$

Menurut ketentuan pasal 16 ayat (m) UUJN Perubahan ini maka suatu akta harus dibacakan dihadapan penghadap dengan dihadiri oleh paling sedikit 2 (dua) orang saksi, sehingga dalam hal ini keberadaan saksi menjadi penting dalam pembuatan suatu akta notaries, keberadaan saksi disebutkan pada akhir akta. Ketentuan mengenai pembacaan akta dihadapan saksi ini bertentangan atau terjadi konflik norma dengan ketentuan dalam Pasal 16 ayat (1) huruf f UUJN Perubahan yang menyatakan bahwa : "merahasiakan segala sesuatu mengenai Akta yang dibuatnya dan segala keterangan yang diperoleh guna pembuatan Akta sesuai dengan sumpah/janji jabatan, kecuali undangundang menentukan lain." Menurut ketentuan ini maka seorang notaris haruslah merahasikan segala sesuatunya mengenai akta yang dibuatnya dan segala keterangan yang diperoleh guna pembuatan akta sesuai dengan sumpah atau janji jabatan, kecuali undang-undang menentukan lain. Permasalahan terjadi karena dalam hal ini kedudukan saksi mengetahui keseluruhan isi dari akta tersebut ataukah hanya sebatas mengetahui para penghadap saja, sehingga dalam tesis ini menarik untuk dibahas lebih lanjut dengan mengangkat judul "Kedudukan Saksi Instrumentair Akta Notaris Dalam

${ }^{3}$ Tan Thong Kie, Op.cit, h. 268 
Kaitannya Dengan Pasal 16 Ayat (1) Undang-Undang Nomor 30 Tahun 2004 Tentang Jabatan Notaris."

\subsection{Rumusan Masalah}

1. Bagaimanakah kedudukan hukum saksi instrumentair dalam kaitannya dengan adanya kewajiban notaris untuk merahasiakan segala sesuatu yang berkenaan dengan akta yang dibuatnya dalam Pasal 16 ayat (1) huruf f UUJN Perubahan?

2. Sejauhmana tanggungjawab saksi instrumentair akta notaris sejalan dengan Pasal 16 ayat (1) huruf $\mathrm{m}$ UUJN Perubahan?

\subsection{Ruang Lingkup Masalah.}

Pada permasalahan pertama dibahas tentang kedudukan hukum saksi instrumentair dalam kaitannya dengan adanya kewajiban notaris untuk merahasiakan segala sesuatu yang berkenaan dengan akta yang dibuatnya dalam Pasal 16 ayat (1) huruf $\mathrm{f}$ UUJN Perubahan.Pada permasalahan kedua, dibahas tentang tanggungjawab saksi instrumentair akta notaris sejalan dengan Pasal 16 ayat (1) huruf m UUJN Perubahan.

\subsection{Tujuan Penelitian}

\subsubsection{Tujuan Umum}

Untuk pengembangan ilmu hukum terkait paradigma Science as a process (ilmu sebagai proses). Dengan paradigma ini, ilmu hukum tidak akan mandek dalam penggalian atas kebenaran, khususnya terkait dengan materi Kedudukan Saksi Instrumentair Akta Notaris Dalam Kaitannya Dengan Pasal 16 Ayat (1) UndangUndang Nomor 30 Tahun 2004 Tentang Jabatan Notaris.

\subsubsection{Tujuan Khusus}

Untuk mendeskripsikan dan melakukan analisis secara mendalam tentang saksi instrumentair dalam kaitannya dengan adanya kewajiban notaris untuk merahasiakan segala sesuatu yang berkenaan dengan akta yang dibuatnya dalam Pasal 16 ayat (1) huruf f UUJN Perubahan. Untuk mendeskripsikan dan melakukan analisis secara mendalam tentang tanggungjawab saksi instrumentair akta notaris sejalan dengan Pasal 16 ayat (1) huruf m UUJN Perubahan.

\subsection{Manfaat Penelitian}

\subsubsection{Manfaat Teoritis}

Untuk menambah wawasan dan ilmu pengetahuan khususnya terhadap hukum perdata di bidang kenotariatan.

\subsubsection{Manfaat Praktis}

Bagi kalangan dibidang hukum perdata dapat dijadikan referensi atau pengetahuan tambahan untuk lebih berhati-hati dalam membuat suatu akta dimana pentingnya posisi seorang saksi instrumentair, manfaat bagi penulis adalah untuk mengembangkan ilmu hukum di bidang Hukum keperdataan dan kenotariatan.

\subsection{Landasan Teoritis}

Adapun asas dan teori teori yang digunakan dalam penelitian ini adalah 1.6.1 Teori Tanggung Jawab

Dalam ranah hukum, seseorang tentu harus bertanggungjawab terhadap kerugian yang diakibatkan oleh perbuatan yang bertentangan dengan hukum dari orang lain. Hal ini disebut tanggung jawab kualitatif, yaitu orang yang bertanggungjawab 
karena orang itu memiliki suatu kualitas tertentu. ${ }^{4}$.

\subsubsection{Teori Kepastian Hukum}

Menurut pendapat Peter Mahmud Marzuki, Teori Kepastian hukum mengandung 2 (dua) pengertian yaitu pertama adanya aturan yang bersifat umum membuat individu mengetahui perbuatan apa yang boleh atau tidak boleh dilakukan, dan kedua berupa keamanan hukum bagi individu dari kesewenangan pemerintah karena dengan adanya aturan hukum yang bersifat umum itu individu dapat mengetahui apa saja yang boleh dibebankan atau dilakukan oleh Negara terhadap individu. Kepastian hukum bukan hanya berupa pasalpasal dalam undang-undang melainkan juga adanya konsistensi dalam putusan hakim antara putusan hakim yang satu dengan putusan hakim lainnya untuk kasus yang serupa yang telah diputuskan. ${ }^{5}$

\subsection{Metode Penelitian}

\subsubsection{Jenis Penelitian}

Jenis penelitian yang digunakan dalam penelitian tesis ini yaitu penelitian hukum normatif, Penelitian hukum Normatif mencakup penelitian terhadap sistematika hukum, penelitian terhadap taraf sinkronisasi hukum, penelitian sejarah hukum dan penelitian perbandingan hukum. ${ }^{6}$

\subsubsection{Jenis Pendekatan}

Dalam penelitian ini akan dibahas menggunakan jenis pendekatan

${ }^{4}$ W. Sommermeijer, 2003, Tanggung Jawab Hukum, Pusat Studi Hukum Universitas Parahyangan, Bandung, h. 23

${ }^{5}$ Peter Mahmud Marzuki, 2008, Pengantar Ilmu Hukum, Kencana Pranada Media Group, Jakarta, h. 158

${ }^{6}$ Soerjono Soekanto, 2000, Pengantar Penelitian Hukum, UI Press, Jakarta, h. 51 analitis, pendekatan konsep dan pendekatan perundang-undangan. ${ }^{7}$

\subsubsection{Sumber Bahan Hukum}

Adapun sumber bahan hukum yang diperoleh dalam penulisan tesis ini yaitu melalui penelitian hukum normatif dengan melakukan penelitian terhadap data sekunder, yaitu data yang diperoleh dari penelitian melalui kepustakaan (Library Research). ${ }^{8}$

\subsubsection{Teknik Pengumpulan Bahan Hukum}

Dalam pengumpulan bahan-bahan hukum dipergunakan teknik studi dokumen, yaitu menelaah peraturanperaturan yang relevan, buku-buku atau bahan-bahan bacaan atau, karya ilmiah para sarjana dan hasilnya dicatat dengan sistem kartu. ${ }^{9}$

\subsubsection{Teknik Analisis Bahan Hukum}

Analisis dilakukan dalam rangka untuk menyelesaikan permasalahan yang ada dengan menggambarkan apa yang menjadi masalah (deskripsi), menjelaskan masalah (eksplanasi), mengkaji permasalahan dari bahanbahan hukum yang terkait (evaluasi) dan memberikan argumentasi dari hasil evaluasi tersebut, sehingga didapat kesimpulan mengenai persoalan yang dibahas pada penelitian ini.

${ }^{7}$ Mukti Fajar, dan Yulianto Achmad, 2010, Dualisme Penelitian Hukum Normatif \& Empiris, Pustaka Pelajar, Yogjakarta, h. 185190

${ }^{8}$ Ronny Hanitijo Soemitro, 2000, Metodologi Penelitian Hukum, Ghalia Indonesia, Jakarta, h. 24.

${ }^{9}$ Bambang Waluyo, 2002, Penelitian Hukum Dalam Praktek, Sinar Grafika, Jakarta, h. 23 
B AB II

TINJAUAN UMUM TENTANG

NOTARIS, AKTA NOTARIS DAN

\section{SAKSI}

\subsection{Tinjauan Umum Tentang Notaris}

\subsubsection{Pengertian Dan Dasar Hukum Notaris}

Menurut ketentuan yang diatur dalam Pasal 1 ayat (1) UUJN menyatakan bahwa : "Notaris adalah pejabat umum yang berwenang untuk membuat akta otentik dan kewenangan lainnya sebagaimana dimaksud dalam undang-undang ini."

\subsubsection{Kewenangan Notaris}

Kewenangan Notaris diatur dalam ketentuan Pasal 15 UUJN Perubahan yang menyatakan bahwa Notaris berwenang membuat Akta autentik mengenai semua perbuatan, perjanjian, dan penetapan yang diharuskan oleh peraturan perundang-undangan dan/atau yang dikehendaki oleh yang berkepentingan untuk dinyatakan dalam Akta autentik, menjamin kepastian tanggal pembuatan Akta, menyimpan Akta, memberikan grosse, salinan dan kutipan Akta, semuanya itu sepanjang pembuatan Akta itu tidak juga ditugaskan atau dikecualikan kepada pejabat lain atau orang lain yang ditetapkan oleh undang-undang.

\subsubsection{Tanggung Jawab Notaris}

Mengenai tanggung jawab notaris selaku pejabat umum yang berhubungan dengan kebenaran materiil, dibedakan menjadi empat poin yakni: Tanggung jawab notaris secara perdata terhadap kebenaran materiil terhadap akta yang dibuatnya; Tanggung jawab notaris secara pidana terhadap kebenaran materiil dalam akta yang dibuatnya; Tanggung jawab notaris berdasarkan PJN terhadap kebenaran materiil dalam akta yang dibuatnya; Tanggung jawab notaris dalam menjalankan tugas jabatannya berdasarkan kode etik notaris. ${ }^{10}$

\subsection{Tinjauan Umum Tentang Akta Notaris}

\subsubsection{Pengertian Akta Notaris}

Menurut Sudikno Mertokusumo "akta notaris adalah akta otentik yang merupakan alat bukti tertulis dengan kekuatan pembuktian sempurna. Ini berarti bahwa masih dimungkinkan dapat dilumpuhkan oleh bukti lawan sehingga hakim wenang untuk membatalkannya."11 Akta notaris menurut ketentuan yang diatur dalam Pasal 1 angka 7 UUJN Perubahan menyatakan bahwa: "Akta Notaris yang selanjutnya disebut akta adalah autentik yang dibuat oleh atau di hadapan notaris menurut bentuk dan tata cara yang ditetapkan dalam undang-undang ini."

\subsubsection{Bentuk-Bentuk Akta Notaris}

Akta-akta yang dibuat oleh Notaris dapat merupakan suatu akta yang memuat "relaas" atau yang menguraikan secara otentik suatu tindakan yang dilakukan ataupun suatu keadaan yang dilihat atau disaksikan oleh Notaris itu sendiri dalam menjalankan jabatannya sebagai Notaris. dapat diketahui bahwa ada 2 (dua) golongan akta notaris, yakni :

10 Nico, 2003, Tanggung Jawab Notaris Selaku Pejabat Umum, Centre For Documentation and Studies of Business Law, Yogjakarta, h. 21

${ }^{11}$ Sudikno Mertokusumo, 1993, Mengenal Hukum Suatu Pengantar, Liberty, Yogjakarta, h. 149 
1) akta yang dibuat "oleh" (door) Notaris atau dinamakan "Akta Relaas" atau "akta pejabat" (ambtelijke akten) sedangkan;

2) akta yang dibuat "dihadapan" (ten overstaan) Notaris atau yang dinamakan "Akta Partij" (partij akten); ${ }^{12}$

\subsubsection{Syarat Akta Otentik}

Suatu akta dapat disebut sebagai akta otentik apabila telah memenuhi unsur sebagaimana yang ditentukan dalam Pasal 1868 KUHPerdata yang menyatakan suatu akta otentik ialah "suatu akta yang didalam bentuk yang ditentukan oleh undang-undang, dibuat oleh atau dihadapan pegawaipegawai umum yang berkuasa untuk itu tempat dimana akta dibuatnya."

\subsubsection{Kekuatan Hukum Akta Otentik}

Hal terpenting dalam masalah kekuatan pembuktian suatu akta otentik ialah kekuatan pembuktiannya yang lengkap. Bukti lengkap ialah bukti yang sedemikian sehingga hakim memperoleh kepastian yang cukup untuk mengabulkan akibat hukum yang dituntut oleh penggugat, tanpa mengurangi kemungkinan adanya bukti tentang kebalikannya. Dari definisi di atas maka dapat disimpulkan bahwa sekalipun suatu akta otentik memiliki suatu kekuatan pembuktian lengkap namun tidak tertutup kemungkinan untuk suatu pembuktian tentang kebalikannya. ${ }^{13}$

\subsection{Tinjauan Umum Tentang Saksi}

\subsubsection{Pengertian Saksi}

Secara umum saksi merupakan alat bukti yang sah, hal ini sebagaimana tercantum dalam 52

12 G.H.S. Lumban Tobing, Op.cit, h. 51-

${ }^{13}$ Setiawan, 1992, Aneka Masalah Hukum dan Hukum Acara Perdata, Alumni, Bandung, h. 405 ketentuan Pasal 1866 KUHPerdata. Sebagai alat bukti yang sah, Saksi adalah Seseorang yang memberikan kesaksian, baik dengan lisan maupun secara tertulis atau tanda tangan, yakni menerangkan apa yang ia saksikan sendiri (waarnemen), baik itu berupa perbuatan atau tindakan dari orang lain atau suatu keadaan ataupun suatu kejadian. ${ }^{14}$ Menurut ketentuan yang diatur Pasal 1 Undang-Undang Nomor 13 Tahun 2006 Tentang Perlindungan Saksi dan Korban menyatakan bahwa: "saksi adalah orang yang dapat memberikan keterangan guna kepentingan penyelidikan, penyidikan, penuntutan, dan pemeriksaan di sidang pengadilan tentang suatu perkara pidana yang ia dengar sendiri, ia lihat sendiri, dan/atau ia alami sendiri."

\subsubsection{Jenis-Jenis Saksi}

Adapun jenis-jenis saksi yang terdapat dalam lalu lintas hukum atau kejadian yang berkaitan dengan hukum dapat digolongkan sebagai berikut: saksi a charge, saksi a de charge, saksi kebetulan, saksi sengaja, saksi mahkota, saksi berantai, saksi anak, saksi pelapor, saksi korban, Testimunium de auditu. Dalam ruang lingkup kenotariatan dikenal dua macam saksi, yaitu saksi kenal dan saksi instrumentair. Saksi instrumentair diwajibkan oleh hukum untuk hadir pada pembuatan akta notaris. Saksi kenal adalah saksi pengenal yang memperkenalkan penghadap kepada notaris. Saksi pengenal terdiri dari dua orang yang berumur paling sedikit 18 (delapan

${ }^{14}$ G.H.S Lumban Tobing, Op.cit, h. 168 
belas) tahun atau telah menikah dan cakap melakukan perbuatan hukum

\subsubsection{Tanggung Jawab Saksi}

Nilai tanggungjawab adalah salah satu nilai yang bisa dipetik dari pelaksanaan hak dan kewajiban seorang saksi. Seorang saksi yang bersaksi dan memberikan keterangan di pengadilan menunjukkan sikap tanggungjawab yang sangat besar dan mendalam. Tanggungjawab bahwa apa yang disampaikan bukan berdasarkan intervensi pihak lain, namun berdasarkan kesadaran akan kehendak bebas untuk menyampaikan sesuatu secara benar berdasarkan nilai-nilai kemanusiaan yang sebenarnya. ${ }^{15}$

\section{B AB III}

\section{SAKSI INSTRUMENTAIR DALAM PEMBUATAN AKTA NOTARIS}

\subsection{Pengaturan Hukum Saksi Instrumentair Dalam Akta Notaris}

KUHPerdata pada Buku keempat Bab ketiga tentang pembuktian dan saksi dalam Pasal 1895KUHPerdata, 1902 KUHPerdata, dan Pasal 1904 sampai 1912 KUHPerdata. Kemudian pengaturan tentang saksi juga terdapat di dalam KUHAP, diantaranya Pasal 1 angka 26, Pasal 159 sampai dengan Pasal 185 KUHAP. Menurut ketentuan yang diatur dalam Pasal 1 angka 26 KUHAP menyatakan bahwa : "saksi adalah orang yang dapat memberikan keterangan guna kepentingan penyidikan, penuntutan dan peradilan tentang suatu perkara pidana yang ia dengar sendiri, ia lihat sendiri dan ia alami sendiri. Saksi juga merupakan

${ }^{15}$ Frans Magnis Suseno, 1987, Etika Dasar; Masalah-Masalah Pokok Filsaat Moral, Kanisius, Yogjakarta, h. 40 alat bukti yang sah." Demikian pula tentang saksi diatur juga didalam Pasal 40 UUJN Perubahan dan di dalam Pasal 20 sampai Pasal 24 Peraturan Jabatan Notaris.

Pada ranah hukum kenotariatan, dalam peresmian suatu akta Notaris, dikenal 2 saksi, yaitu saksi kenal (saksi testamenter) dan saksi instrumentair. Saksi Instrumentair adalah saksi yang yang harus hadir dalam pembuatan suatu akta, dalam arti pembacaan dan penandatanganan suatu akta. Sedangkan saksi kenal atau saksi attesterend adalah saksi yang memperkenalkan penghadap kepada Notaris karena penghadap tersebut tidak mempunyai identitas atau identitasnya diragukan oleh Notaris. Dan hal ini harus dicantumkan dalam akta. Dalam pembuatan akta Notaris, kehadiran saksi adalah merupakan salah satu syarat sahnya suatu akta. Saksi yang menghadiri, menyaksikan dan menandatangani akta adalah saksi instrumentair. ${ }^{16}$

Para saksi instrumentair tidak bertanggungjawab terhadap isi akta itu. Oleh undang-undang tidak diwajibkan secara tegas kepada para saksi untuk merahasiakan isi akta tersebut, sehingga terhadap para saksi instrumentair ini tidak dapat diberlakukan ketentuan dalam Pasal 322 KUHPidana. Saksi instrumentair dalam kedudukannya sebagai saksi tidak menjabat suatu jabatan atau pekerjaan sebagai yang dimaksud dalam pasal tersebut. Oleh karena itu apabila saksi instrumentair membocorkan isi dari suatu akta,

16 Tan Thong Kie, Op.cit, h. 647 
maka perbuatan tersebut merupakan suatu perbuatan melawan hukum sebagaimana yang dimaksud dalam Pasal 1365 KUHPerdata. ${ }^{17}$

\subsection{Syarat-Syarat Saksi Instrumentair}

\section{Dalam Akta Notaris}

Di dalam Pasal 40 UUJN

Perubahan tersebut telah jelas diatur mengenai saksi dalam peresmian dan pembuatan akta notaris yang berupa persyaratan bagi para saksi. Adapun ketentuan yang diatur dalam Pasal 40 UUJNPerubahan, untuk menjadi saksi diantaranya sebagai berikut :

(1) Setiap Akta yang dibacakan oleh Notaris dihadiri paling sedikit 2 (dua) orang saksi, kecuali peraturan perundang-undangan menentukan lain.

(2) Saksi sebagaimana dimaksud pada ayat (1) harus memenuhi syarat sebagai berikut:

a. paling rendah berumur 18 (delapan belas) tahun atau sebelumnya telah menikah;

b. cakap melakukan perbuatan hukum;

c. mengerti bahasa yang digunakan dalam Akta;

d. dapat membubuhkan tanda tangan dan paraf; dan

e. tidak mempunyai hubungan perkawinan atau hubungan darah dalam garis lurus ke atas atau ke bawah tanpa pembatasan derajat dan garis ke samping sampai dengan derajat ketiga dengan Notaris atau para pihak.

(3) Saksi sebagaimana dimaksud pada ayat (1) harus dikenal oleh Notaris atau diperkenalkan kepada Notaris atau diterangkan tentang identitas dan kewenangannya kepada Notaris oleh penghadap.

(4) Pengenalan atau pernyataan tentang identitas dan kewenangan saksi dinyatakan secara tegas dalam Akta.

\subsection{Kedudukan Hukum Saksi}

\section{Instrumentair Bagi Keotentikan Akta}

Notaris

Kedudukan saksi akta Notaris tentunya berbeda dengan kedudukan saksi pada umumnya yang merupakan saksi yang mendengar dan/atau

${ }^{17}$ G.H.S Lumban Tobing, Op.cit, h. 170 melihat sendiri suatu peristiwa yang terjadi. Contohnya dalam suatu peristiwa jual beli, saksi umumnya adalah yang melihat terjadinya penyerahan uang dari pembeli dan penyerahan barang dari penjual. Tetapi pada saksi akta, bisa saja pembeli telah melakukan penyerahan uang secara transfer kepada penjual, dan pada saat penandatanganan akta jual beli, pembeli hanya menunjukkan bukti transfer sebagai bukti telah dilakukannya pembayaran kepada penjual. Demikian juga dalam hal pembayaran pajak penjualan dan pajak pembelian. Para pihak mungkin saja hanya memperlihatkan bukti pembayaran pajak-pajak tersebut. Maka dalam hal ini saksi akta tidak melihat sendiri secara fisik dan tidak mengetahui tentang penyerahan uang tersebut. Dengan kata lain, kedudukan saksi instrumentair adalah untuk memenuhi syarat formal dari suatu akta.

Kedudukan saksi instrumentair sebagai salah satu syarat formal suatu akta Notaris disebutkan dalam Pasal 38 ayat (4) huruf c Undang-undang Nomor 30 Tahun 2004 Tentang Jabatan Notaris bahwa pada akhir atau penutup akta harus memuat nama lengkap, tempat dan tanggal lahir, pekerjaan, jabatan, keedudukan, dan tempat tinggal dari tiap-tiap saksi. Ketika syarat formal ini tidak dipenuhi, akta tersebut terdegradasi kedudukannya menjadi kekuatan pembuktian sebagai akta di bawah tangan. Berdasarkan uraian diatas maka dapat diketahui mengenai kedudukan saksi instrumentair dalam 
suatu akta Notaris bahwa keberadaan

saksi instrumentair dalam suatu akta notaris menjadi salah satu syarat formal untuk membuat suatu akta notaris menjadi akta otentik sebagaimana yang telah diamanatkan oleh Pasal 1868 KUHPerdata dan juga Pasal 40 ayat (1) UUJN Perubahan. Akta Notaris disebut sebagai akta Notaris yang lengkap apabila semua syarat formal dipenuhi, sehingga akta Notaris tersebut mempunyai kekuatan pembuktian sempurna, dan kedudukan saksi akta yang merupakan salah satu syarat formal dalam suatu akta Notaris dapat dipertanggungjawabkan secara hukum.

Dalam kaitannya dengan kewajiban Notaris untuk merahasiakan isi akta sebagaimana diatur dalam ketentuan Pasal 16 ayat (1) huruf 1 UUJN Perubahan kedudukan saksi isntrumentair yang menjadi syarat sah nya suatu akta untuk disebut sebagai akta otentik bukanlah suatu pelanggaran. Kedudukan saksi instrumentair merupakan satukesatuan dalam sebuah akta Notaris, saksi instrumentair yang berasal dari karyawan Notaris dalam prakteknya dilapangan tidaklah selalu karyawan yang mengetik akta para pihak tersebut. Tidak jarang karyawan yang menjadi saksi dalam penandatanganan dan pembacaan akta tersebut mengetahui sebatas pada saat kejadian tersebut berlangsung saja. Sehingga karyawan notaris dalam kedudukannya sebagai saksi instrumentair tidak berkewajiban untuk mengingat isi akta tersebut dalam ingatannya. Sepanjang saksi instrumentair tersebut tidak melakukan perbuatan yang melawan hukum dalam tugasnya sebagai karyawan notaris untuk mengetik akta para pihak, maka keberadaannya dalam suatu akta notaris tidaklah bertentangan dengan ketentuan Notaris wajib merahasiakan isi akta. Menurut penulis, saksi instrumentairpun secara tidak langsung juga berkewajiban untuk merahasiakan isi akta tersebut guna melindungi kepentingan dari para pihak dalam akta dimaksud.

\section{BAB IV \\ TANGGUNG JAWAB SAKSI INSTRUMENTAIR DALAM AKTA NOTARIS}

\subsection{Saksi Instrumentair Dalam Proses Atau Peresmian Akta Notaris}

Saksi yang dicantumkan dalam
akta Notaris adalah saksi
instrumentair, yaitu saksi yang hadir
pada saat pembuatan akta,
membubuhkan tanda tangan mereka, memberikan kesaksian tentang kebenaran adanya dilakukan dan dipenuhinya formalitas-formalitas yang diharuskan oleh undang-undang, yang disebutkan dalam akta itu dan yang disaksikan oleh para saksi itu. Dengan kata lain, saksi instrumentair inilah yang menyaksikan apakah akta tersebut dalam peresmiannya yaitu apakah telah disusun, dibacakan dan ditandatanganinya, telah dilakukan dengan benar oleh Notaris. ${ }^{18}$

Dalam pembuatan suatu akta Notaris, keberadaan saksi-saksi adalah mutlak. Jika suatu akta Notaris tidak melibatkan saksi-saksi maka akta tersebut adalah bukan akta otentik,

${ }^{18}$ G.H.S Lumban Tobing, Op.cit, h. 169 
melainkan suatu akta yang berkekuatan sebagai akta yang dibuat dibawah tangan. Notaris alam peresmian aktanya, harus membacakan akta tersebut di depan para penghadap dan para saksi, untuk kemudian ditandatangani oleh para pihak dan para saksi tersebut. Hal ini juga dijelaskan dalam Pasal 40 UUJN Perubahan dijelaskan bahwa setiap akta yang dibacakan oleh Notaris dihadiri oleh paling sedikit 2 (dua) orang saksi.

Namun dengan demikian bukan berarti para saksi instrumentair tidak mengerti sama sekali terhadap isi suatu akta. Saksi instrumentair yang juga adalah karyawan Notaris jelas mengetahui formalitas-formalitas yang dilakukan dalam hal pembuatan akta tersebut. Karyawan notaris baik juga sebagai saksi instrumentair berperan sejak pengumpulan data-data pendukung dari akta tersebut, pembayaran segala biaya-biaya yang berhubungan dengan pembuatan akta, bahkan sampai dengan pengetikan dan penyaksian pembacaan dan penandatanganan akta, para saksi instrumentair ini sangat memahami segala sesuatu yang terdapat dalam akta itu. Tapi hal ini tidak menyebabkan para saksi tersebut menjadi bertanggungjawab akan segala sesuatu yang nantinya akan terjadi terhadap akta. Karena saksi instrumentair ini hanya menyaksikan apakah notaris telah menjalankan syarat-syarat formalitas pembuatan suatu akta pada saat pembuatan akta tersebut.

\subsection{Hak dan Kewajiban Saksi}

\section{Instrumentair Dalam Akta Notaris}

Implementasi peraturan untuk perlindungan saksi dalam memberikan perlindungan hukum kepada karyawan notaris sebagai saksi instrumentair yang juga menjadi saksi dalam proses peradilan suatu perkara pidana adalah diatur dalam ketentuan Pasal 29 jo Pasal 30 UU Perlindungan Saksi dan Korban. karyawan notaris sebagai saksi dalam suatu proses perkara pidana akan mendapatkan perlindungan dari LPSK terhadap hakhaknya sebagai saksi, diantaranya adalah perlindungan terhadap hak untuk bebas dari ancaman atau tekanan pada saat memberikan kesaksian di dalam pengadilan untuk suatu proses perkara pidana. Dari uraian tersebut terlihat bahwa Undang-Undang Nomor 13 Tahun 2006 tentang Perlindungan Saksi dan Korban memberikan perlindungan hukum kepada karyawan notaris sebagai saksi dalam suatu proses peradilan perkara pidana. Kewajiban untuk merahasiakan isi akta dan keterangan yang diperoleh ini bertujuan untuk melindungi kepentingan masyarakat, khususnya para pihak yang perbuatan hukumnya dikonstantir dalam akta otentik tersebut. Berdasarkan hal tersebut, maka dapat disimpulkan bahwa yang berkewajiban untuk merahasiakan isi akta dan keterangan yang diperoleh dalam pembuatan akta bukan hanya Notaris saja, melainkan semua yang ada di dalam ruangan pada saat verlidjen akta, termasuk para saksi akta. 


\subsection{Tanggung Jawab Saksi Instrumentair}

\section{Akta Notaris}

Banyak Notaris dalam prakteknya yang menjadikan karyawannya sebagai saksi instrumentair, apabila memang memenuhi persyaratan yang ditentukan oleh UndangUndang, dalam hal ini diatur dalam pasal 40 ayat (2) UUJN. Dalam hal melakukan pengetikan dan penyusunan rancangan akta, karyawan notaris bertanggung jawab terhadap hasil pengetikan tersebut telah sesuai dengan rancangan. Sedangkan dalam melakukan pencocokan identitas, nama dari orang - orang yang dicantumkan dalam akta itu harus benar benar sama dengan orang - orang yang bertindak sebagai penghadap pada pembuatan akta itu; mereka yang nama - namanya disebut dalam akta itu harus sesuai dengan orang orang, sebagaimana mereka itu dikenal di dalam masyarakat; nama - nama yang disebutkan dalam akta itu benar- benar dipakai oleh orang - orang yang bersangkutan. Oleh karena itu sebagai karyawan notaris harus mampu mencocokkan identitas dari orang orang yang akan disebut dalam akta sebelum pembuatan akta diresmikan, dalam hal ini pencocokkan identitas tersebut menjadi tanggung jawab karyawan yang bersangkutan, namun tidak terlepas juga dari petunjuk dan arahan notaris.

Dalam peresmian akta, karyawan notaris memiliki tanggung jawab terhadap apa yang diperintahkan atau ditugaskan atau diminta oleh notaris. Dalam hal ini karyawan notaris ditugaskan atau diminta untuk menjadi saksi dalam peresmian akta. Karyawan notaris yang menjadi saksi instrumentair wajib hadir dalam peresmian akta untuk menyaksikan peresmian akta tersebut yaitu pembacaan akta oleh notaris dan penandatanganan akta oleh para penghadap, notaris dan para saksi. Dengan demikian karyawan notaris tidak bertanggung jawab terhadap isi akta yang ditandatanganinya sebagai saksi, mengingat dari sifat kedudukannya sebagai karyawan yang hanya ditugaskan oleh notaris yaitu hanya sebatas untuk mempersiapkan akta tersebut.

Para saksi instrumentair termasuk para karyawan Notaris yang kebetulan menjadi saksi instrumentair, tidak bertanggung terhadap isi akta. Notarislah yang tetap bertanggung jawab akan isi akta tersebut, walaupun untuk sahnya suatu akta disyaratkan adanya saksi, sebagaimana diatur dalam ketentuan pasal 40 ayat (1) UUJN. Tanggung jawab saksi instrumentair dalam hal ini hanya sebatas meyaksikan peresmian akta Notaris tersebut. Akan tetapi tidak bertanggung jawab atas isi akta tersebut. Para saksi tidak perlu harus mengerti apa yang dibacakan itu dan juga bagi mereka tidak ada kewajiban untuk menyimpan isi dari akta itu dalam ingatannya. ${ }^{19}$

\section{BAB V \\ PENUTUP}

\subsection{Kesimpulan}

1. Saksi instrumentair dalam kaitannya dengan adanya kewajiban notaris untuk merahasiakan segala sesuatu yang berkenaan dengan akta yang dibuatnya dalam Pasal 16 ayat (1) huruf f UUJN Perubahan, oleh undang-undang tidak diwajibkan secara tegas kepada para saksi untuk merahasiakan isi akta tersebut, sehingga terhadap para saksi instrumentair ini tidak dapat diberlakukan ketentuan dalam Pasal 322 KUHPidana. Saksi instrumentair dalam kedudukannya sebagai saksi tidak menjabat suatu jabatan atau pekerjaan sebagai yang dimaksud dalam pasal tersebut. Oleh karena itu apabila saksi instrumentair membocorkan isi dari suatu

${ }^{19}$ G.H.S Lumban Tobing, Op.cit, h. 170 
akta, maka perbuatan tersebut merupakan suatu perbuatan melawan hukum.

2. Sesuai dengan ketentuan Pasal 16 ayat (1) huruf $\mathrm{m}$ UUJNPerubahan yang menyatakan kewajiban notaris untuk membacakan akta dihadapan penghadap dengan dihadiri paling sedikit 2 (dua) orang saksi, maka apabila dikaitkan dengan tanggungjawab saksi instrumentair dalam akta notaris maka saksi instrumentair yang berasal dari karyawan notaris dalam hal melakukan pengetikan dan penyusunan rancangan akta, karyawan notaris bertanggung jawab terhadap hasil pengetikan tersebut apakah telah sesuai dengan rancangan. Sedangkan dalam melakukan pencocokan identitas, nama dari orang - orang yang dicantumkan dalam akta itu harus benar - benar sama dengan orang - orang yang bertindak sebagai penghadap pada pembuatan akta itu. Dalam peresmian akta, karyawan notaris memiliki tanggung jawab terhadap apa yang diperintahkan atau ditugaskan atau diminta oleh notaris. Dalam hal ini karyawan notaris ditugaskan atau diminta untuk menjadi saksi dalam peresmian akta. Dengan demikian karyawan notaris tidak bertanggung jawab terhadap isi akta yang ditandatanganinya sebagai saksi, mengingat dari sifat kedudukannya sebagai karyawan yang hanya ditugaskan oleh notaris yaitu hanya sebatas untuk mempersiapkan akta tersebut.

\subsection{Saran}

1. Untuk menjaga kerahasiaan suatu akta notaris seharusnya Undang-Undang Jabatan Notaris juga mengatur mengenai kewajiban dari saksi instrumentair untuk menjaga kerahasiaan dari akta notaris tersebut, hal ini tentunya untuk menghindari terjadinya permasalahan dikemudian hari terkait dengan kebocoran dari isi akta tersebut kepada pihak-pihak lain yang tidak bertanggungjawab.

2. Karyawan notaris yang hanya bertanggungjawab terhadap formalitas akta tentunya harus mendapatkan perlindungan hukum yang jelas apabila kemudian saksi instrumentair tersebut harus menjadi saksi dalam suatu proses pengadilan atas akta Notaris yang mencantumkan namanya sebagai saksi instrumentair, hal ini karena belum tentu saksi instrumentair yang dicantumkan dalam akta tersebut adalah karyawan notaris yang sama yang juga mengetik dan mengetahui detail dari isi akta notaris tersebut.

\section{DAFTAR PUSTAKA}

\section{Buku-buku:}

Bambang Waluyo, 2002, Penelitian Hukum Dalam Praktek, Sinar Grafika, Jakarta

Frans Magnis Suseno, 1987, Etika Dasar; Masalah-Masalah Pokok Filsaat Moral, Kanisius, Yogjakarta

G.H.S., Lumban Tobing, 1999, Peraturan Jabatan Notaris, Erlangga, Jakarta

Mukti Fajar, dan Yulianto Achmad, 2010, Dualisme Penelitian Hukum Normatif \& Empiris, Pustaka Pelajar, Yogjakarta

Nico, 2003, Tanggung Jawab Notaris Selaku Pejabat Umum, Centre For Documentation and Studies of Business Law, Yogjakarta

Peter Mahmud Marzuki, 2008, Pengantar Ilmu Hukum, Kencana Pranada Media Group, Jakarta

Ronny Hanitijo Soemitro, 2000, Metodologi Penelitian Hukum, Ghalia Indonesia, Jakarta

Setiawan, 1992, Aneka Masalah Hukum dan Hukum Acara Perdata, Alumni, Bandung

Soerjono Soekanto, 2000, Pengantar Penelitian Hukum, UI Press, Jakarta 
Sudikno Mertokusumo, 1993, Mengenal Hukum Suatu Pengantar, Liberty, Yogjakarta

Tan Thong Kie, 2000, Studi Notariat \& Serba Serbi Praktek Notaris, Ichtiar Baru Van Hoeve, Jakarta

W. Sommermeijer, 2003, Tanggung Jawab Hukum, Pusat Studi Hukum Universitas Parahyangan,

Bandung

\section{Majalah:}

Sudikno Mertokusumo, 2004, Arti Penemuan Hukum Bagi Notaris, Majalah Renvoi, Nomor 12, tanggal 3 Mei 2004

$$
* * * * *
$$

